Hispania, 2020, vol. LXXX, n. ${ }^{\circ}$ 265, mayo-agosto, págs. 467-496 ISSN: 0018-2141, e-ISSN: 1988-8368, https://doi.org/10.3989/hispania.2020.013

\title{
El obispado y el cabildo eclesiástico de Linares, 1777-1808*
}

\author{
José Gabino Castillo Flores ${ }^{1}$ \\ Universidad Autónoma de Coahuila \\ gabinocastillo@uadec.edu.mx
}

RESUMEN: En este artículo se reseñan los primeros años de existencia del obispado de Linares, creado en 1777, y de su cabildo eclesiástico, constituido en 1790. Tras estudiar las actas capitulares de la catedral y distintos documentos del Archivo General de Indias se muestra que la conformación de dicha diócesis buscaba facilitar la colonización del noreste novohispano que, todavía a finales del siglo XVIII, se encontraba poco poblado y amenazado por ataques de indios nómadas. La historia del cuerpo capitular refleja algunas de las circunstancias adversas que acompañaron la creación del obispado en un territorio de frontera. Asimismo, nos muestra algunas de las posturas que la Corona tuvo ante la Iglesia a finales del Antiguo Régimen y principios del siglo XIX, cuando los tiempos de guerra y la crisis financiera pusieron en riesgo la hegemonía de la monarquía en Indias.

Palabras ClaVE: Monterrey; obispado; catedral; cabildo eclesiástico; prebendados; diezmos.

The bishopric and cathedral chapter of Linares, 1777-1808

ABSTRACT: This article reviews the early years of the Linares bishopric, established in 1777, and its cathedral chapter, constituted in 1790. Based on the

* Este trabajo contó con el apoyo del proyecto «Libros y letrados en el gobierno de las Indias», patrocinado por la Universidad Nacional Autónoma de México, referencia, PAPIIT-IN402218.

Citas de archivo: AGI (Archivo General de Indias, Sevilla); AGN (Archivo General de la Nación, México); AHAM (Archivo Histórico de la Arquidiócesis de Monterrey, México). Agradezco a los directores y a los encargados de estos repositorios la ayuda brindada para su consulta.

${ }^{1}$ ORCID iD: https://orcid.org/0000-0003-2347-3639.

Copyright: (C) 2020 CSIC. Este es un artículo de acceso abierto distribuido bajo los términos de una licencia de uso y distribución Creative Commons Reconocimiento 4.0 Internacional (CC-BY 4.0) 
cathedral's chapter records and documents from the General Archive of the Indies, the diocese is shown to have been formed in order to ease the colonization of the Novo-Hispanic northeast which, by the end of the eighteenth century, was sparsely populated and under threat from nomadic Indians. The history of the cathedral chapter reflects some of the adverse circumstances that accompanied the creation of the bishopric on a frontier territory. The paper also illustrates certain stances adopted by the Crown towards the Church at the end of the Old Regime and the beginning of the nineteenth century, when war and financial crisis put the monarchy's hegemony in the Indies at risk.

KeY WORDS: Monterrey; bishopric; cathedral; ecclesiastical chapter; prebendaries; tithes.

CÓMO CITAR ESTE ARTÍCULO/CITATION: Castillo Flores, José Gabino, «El obispado y el cabildo eclesiástico de Linares, 1777-1808», Hispania, 80/265 (Madrid, 2020): 467-496. https://doi.org/10.3989/hispania.2020.013.

El cabildo eclesiástico de Linares se conformó en 1790, trece años después de que se creara el obispado por bula papal en 1777. Esta diócesis se constituyó en los territorios orientales de la recién establecida Comandancia General de Provincias Internas, proyectada luego de la visita de José de Gálvez. Tanto la comandancia como el obispado fueron medidas tomadas por la Corona para reforzar el control de esta zona donde, por siglos, el avance español se había topado con la resistencia de los indios nómadas del norte. Por esta razón, los Borbones urgieron a sus ministros para fortalecer el control político y religioso sobre las provincias de Nuevo Santander, Nuevo Reino de León, Coahuila y Texas. Este artículo estudia las primeras tres décadas de existencia de este obispado y las dificultades para su constitución en tierras de frontera y en un periodo caracterizado por el debilitamiento de las estructuras políticas de la monarquía a causa de la guerra.

Desde el siglo XVII se había recurrido al sistema de presidios y misiones que sirvieron como enclaves hispanos en la colonización del septentrión novohispano ${ }^{2}$. A pesar de esto, el control territorial seguía siendo parcial. Por esta razón, la Corona decidió, basada en informes de autoridades seglares y eclesiásticas, establecer un obispado con miras a fortalecer las acciones de poblamiento en el noreste novohispano. En un informe de 1769 enviado al Consejo

${ }^{2}$ La colonización del extenso norte novohispano representó un proceso de largo aliento que, además de la presencia española, requirió del apoyo de indios, particularmente tlaxcaltecas, que ayudaron en las labores de conquista y colonización. Estos «indios madrineros», han sido abordados ampliamente en los trabajos de Cecilia Sheridan Prieto. Remito a ella en lo referente al proceso de colonización del noreste novohispano. SHERIDAN PRIETO, 2001; 2015. Sobre este tema véase también VALDÉS, 2017.

Hispania, 2020, vol. LXXX, n. ${ }^{\circ} 265$, mayo-agosto, págs. 467-496, ISSN: 0018-2141, e-ISSN: 1988-8368 https://doi.org/10.3989/hispania.2020.013 
de Indias por el arzobispo de México, Francisco de Lorenzana, después de ser consultado sobre la pertinencia del obispado entonces proyectado con el título de «Nuevo Santander», éste señaló:

Una de las providencias que más ha conducido y nunca ha fallado para el establecimiento de poblaciones, aumento de ellas en estos reinos, formalidad y policía de las ciudades, ha sido la erección de sillas episcopales, pues el celo del obispo y sus capitulares han puesto mejor gobierno en lo eclesiástico. A las capitales han concurrido muchos españoles; la industria y las artes, comercio y labranza se han propagado; los gobiernos se han caracterizado y distinguido; y últimamente hay más trato político y racionalidad entre los naturales; la gentilidad e idolatría se destierra de sus confines; haya abrigo la tropa y hay disposición para los correos ${ }^{3}$.

Como se desprende del informe de Lorenzana, la creación de un obispado no solo servía para demarcar un territorio eclesiástico sino que se consideraba parte de las estrategias de colonización. Ese mismo año de 1769 el virrey Francisco de Croix recibió un informe del mariscal de campo, Juan Fernando Palacios, y del licenciado Joseph de Osorio a quienes había encomendado el reconocimiento de los territorios del Seno Mexicano (colonia del Nuevo Santander). De acuerdo con el escrito, en dicho espacio había ya suficientes poblaciones establecidas y la ganadería y agricultura generaban bastantes ganancias como para fundar un obispado. En su informe, los comisionados señalaron que la pacificación del territorio implicaría un ahorro para la Real Hacienda de más de 580 mil pesos que se invertirían en la manutención de misiones y presidios ${ }^{4}$.

Los comisionados argumentaron que la urgencia de un obispado era evidente por la lejanía de aquellos territorios de las sedes episcopales a las cuales pertenecían: Guadalajara, Michoacán y México. Como aliciente, señalaban que el obispado contaría con buenas rentas decimales; calcularon que el monto que se obtendría de todas las provincias sería de 50 mil pesos, cantidad suficiente para el sostenimiento de la diócesis cuya silla debería colocarse, no en la villa de Santander, como se estaba proyectado, sino en la de Linares, por tener una mejor ubicación. El arzobispo Lorenzana había señalado, además, que la tierra del Nuevo Reino de León era fecunda, el clima benigno y los naturales de buena índole, «robustos y trabajadores», con lo que se conseguiría «ir poniendo freno a los indios gentiles, apaches y de otras castas que infestan las provincias de la Nueva Extremadura y Texas por la parte del norte» ${ }^{5}$. Lo anterior se complementó con un informe del contador general, Tomás Ortiz de Landazuri, quien argumentó que debido a la fertilidad de los terrenos, los diezmos producirían, no los 50 mil pesos proyectados por Palacios y Llamas, sino 80 mil. Con

\footnotetext{
3 AGI, Guadalajara, 555, fs. 130-135.

${ }^{4}$ AGI, Guadalajara, 555, f. 108.

5 AGI, Guadalajara, 555, f. 130.
}

Hispania, 2020, vol. LXXX, n. ${ }^{\circ}$ 265, mayo-agosto, págs. 467-496, ISSN: 0018-2141, e-ISSN: 1988-8368 https://doi.org/10.3989/hispania.2020.013 
esta información, el Consejo determinó, en diciembre de 1773, solicitar al Papa la creación del obispado. La bula se extendió en 1777, por lo que el rey otorgó el título de ciudad a Linares y nombró a fray Antonio de Jesús Sacedón, religioso de la orden de San Francisco y misionero del Colegio Apostólico de Pachuca, primer obispo ${ }^{6}$. La erección del obispado se realizó dos años más tarde.

En suma, este artículo narra parte de un proceso poco abordado por la historiografía hasta este momento: el de la constitución de obispados a finales del periodo virreinal en el septentrión novohispano ${ }^{8}$. Más aún, la aproximación a dicho tema se hace en este trabajo desde el cabildo eclesiástico, corporación que sigue siendo la gran ausente en los trabajos de historia de la Iglesia en México. Si bien existen importantes trabajos sobre dichas corporaciones, éstos se han centrado en los cabildos de las principales catedrales del centro del virreinato9. Considero que el esbozo hecho en este trabajo permitirá conocer un poco más de estas corporaciones y de sus dinámicas eclesiásticas, particularmente, en aquellos obispados que se crearon en las fronteras del imperio.

\section{LA CONFORMACIÓN DEL CABILDO ECLESIÁSTICO. ORÍGENES Y TRAYECTORIA DE SUS MIEMBROS}

En 1779 el obispo Jesús Sacedón llevó a cabo la erección del obispado de Linares. Para formarlo utilizó las constituciones que regían el arzobispado de México, catedral que fungiría como metropolitana. En un informe de ese año el obispo argumentó que había existido un error en el cálculo de los diezmos realizado en 1769 pues se habían proyectado 80 mil pesos cuando éstos apenas llegarían a $31.500^{10}$. Debido a lo anterior, Sacedón dijo estar conformando un cabido eclesiástico que tendría sólo seis miembros ${ }^{11}$. Sin embargo, los conflictos

${ }^{6}$ AGI, Guadalajara, 555, f. 215.

7 AGI, Guadalajara, 555, f. 235.

${ }^{8}$ Entre otros trabajos, véase ENRÍQUEZ LICÓN, 2012 y PANIAGUA PÉREZ, 2013.

${ }^{9}$ Entre estos trabajos pueden consultarse MAZÍN GÓMEZ, 1996. IBARRA, 2000. JARAMILLO MAGAÑA, 2014. CASTILLO FLORES, 2018b. PÉREZ PUENTE, 2016.

${ }^{10}$ AGI, Guadalajara, 555, f. 311.

11 Los cabildos eclesiásticos que surgieron en la nueva España, se basaron en el documento de erección de la catedral de México de 1534. Dicho documento contemplaba 5 dignidades (deán, arcediano, chantre, maestrescuela y tesorero), 10 canónigos, seis racioneros y seis medios racioneros. Las dignidades eran los cargos más importantes y dirigían los principales rubros del gobierno eclesiástico. Los canónigos y racioneros, atendían también cargos que incidían en la administración catedralicia y desempeñaban las principales tareas cultuales cotidianas. A pesar del número estipulado de 27 prebendados, en la práctica el tamaño de los cabildos dependió de las rentas catedralicias. Para conocer más sobre el funcionamiento de los cabildos véase CASTILLO FLORES, 2018b. 
surgidos entre el obispo y el otro comisionado para la erección del obispado, don Eusebio Ventura Beleña, alcalde de crimen de la Audiencia de México, así como la temprana muerte del prelado, ocasionaron que la creación del cabildo quedara en suspenso.

El obispo Sacedón no llegó a residir en Linares. Debido a sus enfermedades, permaneció en la ciudad de Monterrey, capital del Nuevo Reino de León, el poco tiempo que estuvo como obispo entre 1777 y 1779. El siguiente prelado, fray Rafael Joseph Verguer (obispo entre 1783-1790), miembro de la orden de San Francisco y misionero apostólico del colegio de San Fernando, tampoco duró mucho tiempo en el obispado, la muerte lo sorprendió en 1790. Al igual que su predecesor, dicho personaje residió en Monterrey. El año de su muerte, el virrey y el arzobispo de México nombraron a don Gaspar González Candamo, canónigo de Puebla, como gobernador de la diócesis «por no haberse aún establecido cabildo» ${ }^{12}$. El nuevo obispo llegó a Monterrey dos años más tarde, se trataba del doctor don Ambrosio de Llanos y Valdés (1792-1799), antiguo canónigo doctoral de México ${ }^{13}$. Correspondió a este prelado llevar a cabo la conformación del cabildo eclesiástico y consolidar el obispado cuya silla episcopal acabó por transferirse en 1792 a Monterrey, cuya parroquia se erigió en catedral. Esta ciudad había de facto fungido como sede de la diócesis desde sus inicios ${ }^{14}$. En este sentido, al obispado igual se lo conoció como «obispado de Linares» que como «obispado del Nuevo Reino de León».

El cabildo catedral era la corporación eclesiástica más importante de cada diócesis. A ella pertenecían clérigos con experiencia en el culto divino y con estudios universitarios que apoyaban al prelado en la administración del obispado. Pertenecer a dicho cuerpo representaba el culmen de la carrera eclesiástica. Las tareas de sus miembros eran rezar el oficio divino en su catedral, administrar las rentas del obispado, auxiliar al obispo en la administración de la diócesis y gobernarla en los periodos de sede vacante. Por tal razón, la historia de los cabildos y de sus miembros es de suma importancia para comprender las dinámicas eclesiásticas de la Iglesia en América. En este apartado exploraremos los perfiles de quienes ocuparon alguna prebenda en el obispado de Linares, esto nos permitirá comprender mejor las dificultades enfrentadas por aquel obispado para constituirse y consolidarse en un territorio de frontera.

2 AGI, Guadalajara, 552, f. 27.

13 AGI, Guadalajara, 553.

14 GONZÁLEZ, 1877: 126. En 1790 al empezar las dotaciones del cabildo eclesiástico se señaló por la Cámara: «Que permaneciera por ahora la silla episcopal del Nuevo Reyno [sic] de León en la ciudad de Monterrey, celebrándose en su iglesia los divinos oficios, fijándose interinamente en ella el culto y asistencia de los canónigos que se nombraran para componer el nuevo cabildo», AGI, Guadalajara, 553, f. 117. 
Las primeras consultas para nombrar el cuerpo capitular se hicieron en 1789. Para los primeros nombramientos la Cámara de Indias se basó en un informe remitido en 1785 por el obispo Verguer recomendando sujetos para las prebendas de la nueva diócesis. Entre los sugeridos destacaban los curas que servían en el gobierno episcopal y en las parroquias de las provincias de Coahuila y del Nuevo Reino de León. El cabildo quedó constituido en 1790 por seis miembros (deán, chantre, canónigo doctoral, canónigo penitenciario ${ }^{15} \mathrm{y}$ dos racioneros) los cuales comenzaron sus funciones en su catedral al año siguiente.

Joseph Furundarena, elegido deán, había sido propuesto por el obispo Verguer en su listado de 1785. Se trataba de un americano, antiguo colegial de San Pedro y San Pablo y de San Ildefonso en la ciudad de México. Se graduó como licenciado en Cánones por la universidad de aquella ciudad y sirvió como abogado de las audiencias de México y Guadalajara antes de pasar a Monterrey, donde el obispo Verguer lo nombró su provisor ${ }^{16}$. Por su parte, Andrés Feliu, nombrado chantre, fue el único que parece no haber tenido experiencia americana antes de servir su prebenda. Al momento de ser nombrado estaba sirviendo como cura del Hospital General de la Corte en Madrid.

En lo que se refiere a los canónigos de oficios, fueron nombrados Ramón Canalizo, americano, quien al igual que Furundarena había sido colegial de San Pedro y San Pablo. Se graduó como doctor en Cánones en la Universidad de México y sirvió como abogado de la Audiencia antes de pasar a Durango donde fue abogado de cámara del obispo y provisor y vicario general interino de dicho obispado ${ }^{17}$. Por su parte, Matías López, otro americano, llevaba siete años sirviendo el curato de la ciudad de Linares. Era licenciado en Teología por la Universidad de México y había sido catedrático del seminario conciliar de Guadalajara $^{18}$. Ambos canónigos de oficio fueron nombrados por el rey sin mediar concurso de oposición debido a la necesidad de cubrir dichas prebendas en corto tiempo, razón por la cual al momento de nombrarlos se colocó la frase: «dispensando por esta vez los ejercicios».

${ }^{15}$ A inicios del siglo XVII, cuatro de las 10 canonjías, conocidas como «de gracia», se convirtieron en «canonjías de oficio» (doctoral, magistral, lectoral y penitenciaria): para obtenerlas se debía contar con el grado de doctor y llevar a cabo un examen público de oposición. Sobre las canonjías de oficio consúltese PÉREZ PUENTE, XXXVI/1 (Lima, 2012): 53-96.

${ }_{16}$ AGI, Guadalajara, 553, f. 119.

17 AGI, Guadalajara, 552, f. 44.

18 AGI, Guadalajara, 553, f. 119.

Hispania, 2020, vol. LXXX, n. ${ }^{\circ} 265$, mayo-agosto, págs. 467-496, ISSN: 0018-2141, e-ISSN: 1988-8368 https://doi.org/10.3989/hispania.2020.013 
CuAdro 1. Miembros del primer cabildo eclesiástico, 1790

\begin{tabular}{|c|c|c|c|c|}
\hline Nombre & $\begin{array}{c}\text { Año de } \\
\text { presentación }\end{array}$ & Prebenda & Origen & Grado \\
\hline Pedro Joseph Furundarena & 1790 & Deán & A & Licenciado \\
\hline Andrés Feliu y Togores & 1790 & Chantre & E & Doctor \\
\hline Antonio Ramón Canalizo & 1790 & Doctoral & A & Doctor \\
\hline Matías López Prieto & 1790 & Penitenciario & A & Licenciado \\
\hline $\begin{array}{c}\text { Joseph Miguel Sánchez } \\
\text { Navarro }\end{array}$ & 1790 & Ración & A & Bachiller \\
\hline Cipriano García Dávila & 1790 & Ración & A & Bachiller \\
\hline Francisco Juan de Pazos & 1791 & Ración & E & Sin información \\
\hline
\end{tabular}

Fuente: elaboración propia a partir de AGI, Guadalajara, 552 y AGI, Guadalajara, 553.

Finalmente, los racioneros elegidos en 1790 fueron Miguel Sánchez Navarro, oriundo de Saltillo, cura de Monclova en la provincia de Coahuila ${ }^{19}$, quien fue colector de diezmos de aquella región. El obispo Verguer lo había recomendado en su informe de 1785. No obstante, su interés en los negocios familiares lo llevaron a renunciar a su prebenda en $1793^{20}$. Por su parte, Cipriano García, otro clérigo que apareció en la lista del obispo, llevaba 30 años sirviendo como cura de la villa de Cadereyta en el Nuevo Reino de León. No obstante, dicho personaje murió sin haber tomado posesión de su prebenda ${ }^{21}$, la cual se otorgó al año siguiente a Francisco Juan de Pazos, prebendado interino de la diócesis de Durango ${ }^{22}$. Así quedó compuesto el primer cabildo eclesiástico de Linares en 1790. Se trató de un cabildo con apenas seis prebendas. La composición de este cabildo primigenio anunciaba lo que sería común en el perfil de los prebendados de dicha corporación: clérigos con experiencia en el gobierno diocesano en el propio obispado o bien en las mitras de Durango y Sonora.

Gracias a que las rentas decimales aumentaron entre 1796 y 1798, según veremos más adelante, el rey creó nuevas prebendas para el cabildo. Por consulta de Cámara de 11 de septiembre de 1797 se crearon las tres dignidades restantes: arcedianato, tesorería y maestrescolía. La primera prebenda recayó en Antonio Ramón Canalizo quien servía desde 1790 la chantría de la misma

\footnotetext{
19 MARTÍNEZ, 2014.

${ }^{20}$ Su prebenda fue otorgada a Joseph Franco López Portillo, cura de Mazatlán, en 1795, AGI, Guadalajara, 553, f. 74.

${ }_{21}$ AGN, Reales Cédulas Originales, volumen 229, expediente 76.

22 AGI, Guadalajara, 553, f. 67.
} 
catedral. A su vez, la chantría vacante fue dada a Andrés de Ymar, clérigo de origen europeo que servía entonces una ración de la iglesia de Monterrey. Había estudiado en los Reales Estudios de San Isidro, en Madrid, donde se graduó como doctor en Cánones ${ }^{23}$. La otra prebenda de reciente creación fue la maestrescolía, otorgada al bachiller Joseph Francisco López Portillo, americano, entonces racionero del mismo cabildo. Portillo había servido por 24 años el curato del presidio Mazatlán, en el obispado de Sonora, que, según dijo, «equivalen a doble tiempo en otra parte por su mal temperamento» ${ }^{24}$. Portillo fue cercano al obispo de Sonora, fray Joseph Joaquín Granados, y parece que entabló buenas relaciones con los prelados de Guadalajara y México donde estuvo como residente.

Por último, en la tesorería se nombró al bachiller Joseph María Gómez de Castro, americano, cura de los valles de Pilón y Mota en el obispado de Linares. Castro se graduó como bachiller por la Universidad de México, sirvió por 15 años como teniente de cura en Linares y dos como cura propietario de la misma parroquia. Entre sus méritos estaban también el haber servido durante un año y cuatro meses como cura, vicario y juez eclesiástico de la villa de Cadereyta. En 1789 había ganado en propiedad el curato de Valles, al que entonces servía ${ }^{25}$.

CuAdro 2. Dignidades del cabildo eclesiástico entre 1790-1808

\begin{tabular}{|c|c|c|c|c|}
\hline Nombre & $\begin{array}{c}\text { Año de } \\
\text { presentación }\end{array}$ & Prebenda & Origen & Grado \\
\hline Pedro Joseph Furundarena & 1790 & Deán & A & Licenciado \\
\hline Andrés Feliu y Togores & 1790 & Chantre & E & Doctor \\
\hline Andrés Feliu y Togores & 1792 & Deán & E & Doctor \\
\hline Antonio Ramón Canalizo & 1792 & Chantre & A & Doctor \\
\hline Antonio Ramón Canalizo & 1798 & Arcediano & A & Doctor \\
\hline Andrés de Ymar y Altolaguirre & 1798 & Chantre & E & Doctor \\
\hline $\begin{array}{c}\text { Joseph María Gómez de } \\
\text { Castro }\end{array}$ & 1798 & Tesorero & A & Bachiller \\
\hline $\begin{array}{c}\text { Joseph Francisco López } \\
\text { Portillo }\end{array}$ & 1798 & Maestrescuela & A & Bachiller \\
\hline
\end{tabular}

Fuente: elaboración propia a partir de AGI, Guadalajara, 552 y AGI, Guadalajara, 553.

\footnotetext{
${ }^{23}$ AGI, Guadalajara, 552, f. 44.

${ }^{24}$ AGI, Guadalajara, 552, f. 48.

25 AGI, Guadalajara, 552, f. 54.
}

Hispania, 2020, vol. LXXX, n. ${ }^{\circ} 265$, mayo-agosto, págs. 467-496, ISSN: 0018-2141, e-ISSN: 1988-8368 https://doi.org/10.3989/hispania.2020.013 
Como puede apreciarse, en el momento de elegir a los prebendados para la catedral de Monterrey, las autoridades regias prefirieron a clérigos habituados a servir en territorios agrestes como lo era el del Nuevo Reino de León, región asediada aún por indios nómadas en su parte septentrional y castigada por un clima húmedo y caluroso. Entre el perfil de los considerados para estas prebendas sobresalió la formación académica. La mayoría de los prebendados obtuvieron sus grados en la Universidad de México después de haber estudiado en los seminarios diocesanos de Durango, Guadalajara y Monterrey, este último creado en 1793. Asimismo, sobresalió la labor en curatos de presidios. Algunos de los propuestos como prebendados habían participado incluso en algunas incursiones contra «indios bárbaros». Otros más, sirvieron como capellanes de fragata y como capellanes castrenses al lado de los ejércitos del rey. Estos méritos cobraron gran relevancia en una época de guerras, particularmente a fines del siglo XVIII y en un espacio de frontera donde se trataba de mantener el control regio ante las amenazas de invasiones extranjeras. Juvenal Jaramillo ha llamado la atención sobre la importancia que cobraron los capellanes militares a finales del siglo XVIII, personajes cortos en letras, pero cuyos servicios en las armas a favor de la Iglesia y del rey les valieron alguna prebenda ${ }^{26}$.

El caso de las canonjías no fue tan diferente. Hemos señalado que en 1790 se crearon dos canonjías de oficio: la doctoral y la penitenciaria. La primera, dada a Ramón Canalizo, quedó vacante después del ascenso de éste a la chantría en 1792. En 1795 dicha prebenda fue otorgada al licenciado Pedro Ignacio de Salazar, quien entonces era cura del sagrario de la catedral de Durango ${ }^{27}$. Era frecuente que los nombrados que servían en esta catedral tardarán meses, incluso años, en llegar a la misma, por los riesgos que implicaba el viaje. Por eso no extraña que en 1795, cuando el obispo Ambrosio de Llanos y Valdés solicitó al rey una ración en Linares para su sobrino, pusiera como pretexto lo mal atendido del coro debido al tiempo que tardaban en llegar los prebendados.

... se compone todo el cabildo de seis prebendados que son dos dignidades, dos canónigos de oficio y dos racioneros, de tal suerte que cuando hay alguna vacante si ocurre al mismo tiempo indisposición o ausencia de otros, se halla sin poderse servir el culto de aquella catedral, y estando en el día vacante esta ración y la canonjía doctoral, que aunque hace poco tiempo se proveyó en el licenciado don Pedro Ignacio Salazar, cura del obispado de Durango, podrá tardar en tomar la posesión a causa de la larga distancia, puede considerarse en el día como si hubiese sólo cuatro individuos y de consiguiente no podrá estar bien servido el culto de aquella iglesia ${ }^{28}$.

\footnotetext{
26 JARAMILLO MAGAÑA, 2014: 136-137.

27 AGI, Guadalajara, 553, f. 162.

28 AGN, Indiferente Virreinal, caja 3783, expediente 004.
} 
El siguiente en ocupar la canonjía doctoral fue el licenciado don Miguel Ignacio de Zárate, abogado de la Real Audiencia de Guadalajara. Zárate había estudiado gramática en el seminario de esa ciudad y filosofía en el colegio de San Ildefonso de México antes de graduarse como licenciado en Cánones en la Universidad de Guadalajara $^{29}$. Su nombramiento se realizó en 1798 , no sin que antes el fiscal de la Cámara de Indias lanzara una reprimenda al cabildo por demorar tanto el concurso de oposición. El último personaje en ocupar esta canonjía en el periodo estudiado fue Joseph León Lobos, provisor y vicario general de la diócesis de Linares en 1810. Esto ocurrió tras el ascenso de Zárate a una canonjía de gracia de la catedral de Guadalajara. No existen muchos datos de este personaje, del cual se menciona que fue designado, en nombre de Fernando VII, por «el Consejo de Regencia de España e Indias», porque el rey se encontraba cautivo por los franceses.

Cuadro 3. Canónigos del cabildo eclesiástico entre 1790-1808

\begin{tabular}{|c|c|c|c|c|}
\hline Nombre & $\begin{array}{c}\text { Año de } \\
\text { presentación }\end{array}$ & Prebenda & Origen & Grado \\
\hline Antonio Ramón Canalizo & 1790 & Doctoral & A & Doctor \\
\hline Matías López Prieto & 1790 & Penitenciario & A & Licenciado \\
\hline Pedro Ignacio Salazar & 1795 & Doctoral & Licenciado \\
\hline Miguel Ignacio Zárate & 1798 & Doctoral & A & Licenciado \\
\hline Juan Isidro Campos & 1798 & $\begin{array}{c}\text { Canónigo de } \\
\text { merced }\end{array}$ & E & $\begin{array}{c}\text { Sin } \\
\text { información }\end{array}$ \\
\hline Joseph Vivero & 1798 & $\begin{array}{c}\text { Canónigo de } \\
\text { merced }\end{array}$ & A & Licenciado \\
\hline Juan Antonio de la Peña & 1799 & Penitenciario & Licenciado \\
\hline Juan Joseph de la Garza & 1805 & Lectoral & A & Licenciado \\
\hline Joseph Bernardino Cantú & 1805 & Magistral & A & Doctor \\
\hline Domingo de Ugarte & 1805 & Penitenciaria & E & Doctor \\
\hline Joseph León Lobos & 1810 & Doctoral & Doctor \\
\hline
\end{tabular}

Fuente: elaboración propia a partir de AGI, Guadalajara, 552 y AGI, Guadalajara, 553.

Por su parte, la canonjía penitenciaria, ocupada en 1790 por Matías López Prieto fue dada por concurso de oposición en 1798. En dicho concurso

${ }^{29}$ AGI, Guadalajara, 552, f. 85. 
participaron los licenciados Joseph Antonio de la Peña y Pedro Rodríguez Velarde. Este último obtuvo el primer lugar luego de las votaciones del obispo y cabildo eclesiástico. En aquella ocasión el asistente real, fray Ignacio María de Nava, tuvo una buena impresión de Peña, pero advirtió que no tenía «los cuarenta años que pide el concilio y lo mismo que previene la Real Cédula de 2 de octubre de $1796{ }^{30}$. No obstante, Rodríguez Velarde falleció el mismo año de su designación por lo que, en enero de 1799, Peña envió un memorial a la corte argumentando que estaba a punto de tener la edad requerida por lo que suplicaba se le otorgara dicha canonjía, lo cual ocurrió ese mismo año. Peña tampoco duró mucho en el cargo, parece haber muerto hacia 1803. A inicios del año siguiente la canonjía penitenciaria volvió a concursarse. En esa ocasión se apuntaron para el concurso los doctores Domingo de Ugarte, Joseph de Arroyo y Domingo Sariñana. No obstante, los dos últimos terminaron por declinar su participación. A pesar de lo anterior, Ugarte llevó a cabo sus lecciones ante el obispo, cabildo y asistente real, cargo que ocupó Pedro de Fuentes, cura de Saltillo $^{31}$. Ugarte era natural del señorío de Vizcaya en España, no obstante, parece que llegó a México siendo joven pues se menciona que estudió en el colegio de San Buenaventura y luego obtuvo el bachillerato en Filosofía por la Universidad de México. Este grado lo obtuvo alrededor de 1790 pues tres años después lo encontramos en Monterrey sirviendo como el primer rector del colegio seminario fundado dicho año ${ }^{32}$. En 1799 se le nombró racionero de la catedral mientras servía también como capellán y maestro de pajes del obispo Ambrosio de Llanos y Valdés. El cargo de rector del seminario lo mantuvo hasta 1803, entonces pasó a México, donde se doctoró en Teología por la Universidad. Tras volver a Monterrey ganó la canonjía penitenciaria en 1805.

En 1797 se crearon cuatro nuevas canonjías, dos de oficio y dos de gracia. Las de oficio fueron la lectoral y la magistral, las cuales vinieron a completar las cuatro que desde el concilio de Trento estaba mandado que se fundaran en las catedrales de la monarquía. No obstante, a pesar de que dichas canonjías lectoral y magistral se crearon en 1797, no se otorgaron sino hasta 1805 . La lectoral, por ejemplo, la ganó en concurso de oposición Juan Joseph de la Garza, quien ostentaba entonces el cargo de cura del sagrario de la catedral del Nuevo Reino de León. Dicho personaje era oriundo de Monterrey, estudió teología en el colegio de San Miguel el Grande, donde también fue catedrático de latinidad, y se graduó como bachiller en Filosofía por la Universidad de México en $1787^{33}$. Tras ser bachiller, obtuvo el curato de la villa de Oaxaca en el obispado de Antequera. A principios del siglo XIX lo encontramos en Guadalajara, en

\footnotetext{
30 AGI, Guadalajara, 553, f. 183.

${ }^{31}$ AGI, Guadalajara, 553, f. 188.

32 CAVAZOS GARZA, 1969: 416.

33 AGI, Guadalajara, 552, f. 160.
}

Hispania, 2020, vol. LXXX, n. ${ }^{\circ}$ 265, mayo-agosto, págs. 467-496, ISSN: 0018-2141, e-ISSN: 1988-8368 https://doi.org/10.3989/hispania.2020.013 
cuya universidad de graduó como licenciado en Teología. Por su parte, la canonjía magistral se dio a Joseph Bernardino Cantú, quien en ese momento estaba al frente del curato, vicaría y juzgado eclesiástico de Huajuco en el propio obispado de Linares ${ }^{34}$. Cantú era originario de Monterrey donde empezó sus estudios, luego fue colegial en San Miguel el Grande y en México, antes de doctorarse por la Universidad de Guadalajara ${ }^{35}$. Se sabe, además, que fue catedrático de Filosofía en el seminario conciliar de Monterrey.

Como puede observarse hasta aquí, la Universidad de México era la corporación más importante en la formación académica de los futuros prebendados. No obstante, la Universidad de Guadalajara figuraba ya como la segunda en importancia en el otorgamiento de grados a los futuros canónigos. Cabría señalar, además, que el seminario de Monterrey, desde finales del siglo XVIII, se consolidó como una importante institución donde los futuros prebendados de Linares empezaron su carrera clerical.

Durante este periodo fue común que pocos prebendados se presentaran a los concursos de oposición para las canonjías de oficio del obispado de Linares. Entre las razones más importantes de esta negativa estaba la lejanía de aquella catedral recién fundada en tierras de frontera y el clima malsano que caracterizaba a la ciudad episcopal. A lo anterior se sumaba que sus rentas eran bajas, alrededor de 1.000 pesos, razón por la cual pocos prebendados con excelentes carreras universitarias, como debían tenerlas los ocupantes de estas prebendas, se aventuraban a concursarlas. Así lo expresó fray Francisco de Padilla, comisario de la Provincia Franciscana de Jalisco en 1805, cuando atestiguó en favor de la renuncia del recién elegido racionero José Cabo Franco:

... sabe por personas fidedignas y es público y notorio que el temperamento de Monterrey es muy cálido y húmedo. Que le consta, con ocasión de ser catedrático de la universidad de Guadalajara, que en el año pasado de mil ochocientos dos vio fijados por segunda vez en las puertas del aula mayor, edictos convocatorios de la catedral de Monterrey para las canonjías lectoral, penitenciaria y magistral, los que se prorrogaron hasta el siguiente año de mil ochocientos tres, y siendo así que en dicha ciudad de Guadalajara hay un número competente de eclesiásticos pobres y habilitados para obtenerlas, observó que no hubo uno sólo que suscribiera al concurso, antes sí, por el contrario, sabe que don José Tamayo, racionero de la mencionada iglesia de Monterrey, bajó a la de Guadalajara a pretender la maestría de ceremonias, prefiriendo este corto empleo ministerial al decoroso destino capitular que renunció por la insalubridad del temperamento, confirma todo lo dicho constándole que los pretendientes a prebendas comúnmente en los poderes que dan a sus agentes encargan la exclusión de las piezas de Monterrey por ser mal sano su temperamento y de una dotación tan escasa que apenas sufraga para la manutención con grande economía ${ }^{36}$.

\footnotetext{
${ }^{34}$ AGI, Guadalajara, 552, f. 170.

${ }^{35}$ CAVAZOS GARZA, 1969: 412.

${ }^{36}$ AGI, Guadalajara, 553, f. 318.
} 
Lo anterior podría explicar en buena medida la mayor presencia de clérigos americanos y, particularmente, de clérigos locales, en el cabildo neoleonés, pues difícilmente los clérigos de diócesis más ricas aceptaron una prebenda en esta catedral fronteriza y con rentas escasas. Un buen número de prebendados de origen español también ocupó cargos en aquella catedral, no obstante, los que aceptaron estos nombramientos llevaban tiempo sirviendo en parroquias del septentrión novohispano.

Esta misma lógica se reflejó en las dos nuevas canonjías de gracia, creadas en 1797. La primera de ellas se otorgó a Juan Isidro Campos, quien había sido presentando como racionero de Linares el mismo año. Era español, pero llevaba tiempo sirviendo como cura coadjutor, examinador sinodal, vicario y juez eclesiástico de la villa de Chihuahua, en la diócesis de Durango ${ }^{37}$. Desde, al menos, 1783 Campos se encontraba en dicha diócesis pues aparece como familiar del obispo don Esteban Tristán, quien le nombró «visitador de todas las misiones y presidios de la frontera, subdelegándole las facultades castrenses $\rangle^{38}$. Además de ello, le comisionó «para que recogiera cuantos papeles sediciosos se introdujeran en aquel partido después de declarada la guerra con la Francia».

La segunda canonjía de merced, recién creada, fue dada a Joseph Vivero, cura interino del sagrario de Monterrey, provisor, vicario general y examinador sinodal de aquel obispado. Vivero era oriundo de San Luis Potosí, inició sus estudios en el convento de Nuestra Señora de las Mercedes de la villa de Aguascalientes. Más tarde, viajó a San Miguel el Grande, donde cursó Filosofía becado en el real Colegio de San Francisco de Sales. Obtuvo el bachillerato en Filosofía en la Universidad de México en 1778 y, en Cánones, en 1782. Sirvió como abogado de la Real Audiencia de Guadalajara y como teniente de cura en la villa de Aguascalientes. El obispo de Monterrey, don Ambrosio de Llanos Valdés lo nombró su provisor y vicario general, además de gobernador del obispado ante sus ausencias. Asimismo, lo designó catedrático de Teología moral en el seminario tridentino de aquella ciudad. En 1797, un año antes de recibir su canonjía, Vivero obtuvo, en calidad de cura interino, el sagrario de la catedral ${ }^{39}$.

\section{LAS DESPRECIADAS RACIONES}

Hemos señalado arriba que, desde 1790, en la catedral de Monterrey fueron creadas dos raciones, las cuales se entregaron a Joseph Miguel Sánchez Navarro y a Cipriano García Dávila, no obstante, este último personaje murió sin tomar posesión de su prebenda, la cual se dio a Francisco Juan de Pazos al año

\footnotetext{
37 AGI, Guadalajara, 552, f. 55.

38 AGI, Guadalajara, 552, f. 55.

39 AGI, Guadalajara, 552, f. 107.
}

Hispania, 2020, vol. LXXX, n. ${ }^{\circ}$ 265, mayo-agosto, págs. 467-496, ISSN: 0018-2141, e-ISSN: 1988-8368 https://doi.org/10.3989/hispania.2020.013 
siguiente, quien tampoco la sirvió. Al igual que con las otras prebendas, el aumento en los diezmos a partir de 1796 hizo que un año después el rey creara cuatro nuevas raciones, cubriendo así el total de seis raciones que solía haber en las catedrales novohispanas. En el periodo aquí estudiado las raciones fueron las prebendas en las que se dio un mayor número de movimientos por muertes, ascensos y renuncias. Entre 1790 y 1808 se hicieron 21 presentaciones, de las cuales sólo 9 fueron efectivas.

Empecemos por revisar las ausencias por muerte. El primero de ellos fue el ya mencionado bachiller Cipriano García, cura de Cadereyta que murió sin poder servir su prebenda en 1790. El segundo en la lista fue el bachiller Andrés Ramón Lozano, cura castrense y capellán del real presidio de la Bavia, en el valle de Santa Rosa, presentado en 1799. Entre 1784 y 1788, por designación del Comandante General de las Provincias Internas, este personaje sirvió como capellán de la compañía volante del Saltillo. Entre sus méritos contaba el hecho de que, residiendo en el valle de Santa Rosa, salió «con la tropa en diferentes ocasiones para ahuyentar los indios bárbaros que insultaron aquel presidio» ${ }^{40}$, lo que le había ganado las recomendaciones del virrey y del gobernador don Miguel de Emparam. No obstante, la muerte lo sorprendió sin poder tomar posesión de su beneficio.

Por otro lado, estuvieron los clérigos que no ocuparon su ración por el hecho de que fueron presentados, casi de inmediato, a una prebenda de mayor jerarquía. Se trató de dos personajes, el primero de ellos fue Francisco Juan de Pazos, prebendado interino de Durango, presentado en 1791. Debido a que ese mismo año fue presentado a una ración de Durango, no tomó posesión de la de Monterrey. Un caso similar fue el de Juan Isidro Campos, cura de la villa de Chihuahua, nombrado racionero de Linares en 1798 y, casi de manera simultánea, canónigo de merced en la misma iglesia, prebenda ésta última de la que sí tomó posesión.

Por último, tenemos el caso de quienes decidieron renunciar a sus nombramientos. Estos casos son muy interesantes porque nos permiten conocer la idea que se tenía del obispado neoleonés por parte de los clérigos, es decir, existía una visión negativa del obispado, como hemos señalado arriba, por su ubicación en tierras de frontera, su clima malsano y lo bajo de sus rentas. Para entender el elevado número de renuncias, ocho en total, es necesario recordar que el salario de las raciones era de 700 pesos, cantidad nada halagadora para clérigos que habitaban en obispados alejados de Monterrey y que, muchas veces, podían ganar lo mismo o un salario mayor sirviendo como curas párrocos en sus diócesis. Un caso ejemplar es el Joseph Pedro Bustillo y Ceballos, cura y juez

${ }^{40}$ AGI, Guadalajara, 552, f. 66.

Hispania, 2020, vol. LXXX, n. ${ }^{\circ}$ 265, mayo-agosto, págs. 467-496, ISSN: 0018-2141, e-ISSN: 1988-8368 https://doi.org/10.3989/hispania.2020.013 
eclesiástico del partido de Tirindaro, en el obispado de Michoacán. Presentado en 1799, renunció argumentando que le era:

... moralmente imposible pasar a servir dicha prebenda por tener a su cargo crecido número de parientes pobres y de circunstancias, los que no puede desamparar ni llevarlos consigo a tan larga distancia y a donde tampoco los podría mantener por la cortedad de la renta [la cual] no es equivalente a la que tengo en mi beneficio cural $^{41}$.

Por tal razón, Bustillo suplicó al rey admitirle la renuncia sin que ello afectara su consideración para otras prebendas. Pero dejó muy claro que si se le promovía, su «pretensión» se limitaba a las catedrales de México, Puebla, Valladolid y Guadalajara, «y a cualquier otra fuera de estas de ninguna manera aunque sea canonjía» ${ }^{42}$. Algo similar a su caso fue el de Antonio Martín Fajardo, «teniente de cura de la villa de Hincha en la diócesis de Santo Domingo», quien renunció en consideración de la distancia que mediaba hasta Monterrey y los bajos ingresos de aquellas raciones.

Al igual que ellos, otros personajes también renunciaron, aunque, con el afán de no ser tan explícitos, pusieron como pretexto alguna enfermedad que podría agravarse por el viaje hasta Monterrey o bien por el clima de aquella provincia. El bachiller Miguel Sánchez Navarro, ex cura de Monclova, por ejemplo, sirvió su ración sólo dos años; renunció en 1793 argumentando enfermedades que le impedían asistir al coro. No obstante, sus compañeros de cabildo señalaron al rey que dicho personaje poseía ricas haciendas en la provincia de Coahuila, a donde solía irse por largas temporadas, descuidando sus obligaciones. Por su parte el bachiller Joseph María de Ortigosa, cura párroco y juez eclesiástico del partido de San Francisco Huehuetlán, en el obispado de Oaxaca, presentado en 1799, renunció argumentando la imposibilidad de tomar posesión «por la distancia de cuatrocientas leguas y hallarse padeciendo una inflamación reumática en las piernas» ${ }^{43}$.

Caso similar fue el de Francisco de Paula y García, nombrado en 1799. Era natural de Cádiz y había estudiado en el convento de trinitarios calzados de Granada. Era bachiller, licenciado y doctor en Cánones por la Universidad de Orihuela y había sustituido cátedras en la Universidad de Granada ${ }^{44}$. No obstante, cuando fue presentado, Paula presentó certificados de un médico, argumentando que no podía partir hacia América por «hallarse a la sazón gravemente enfermo ${ }^{45}$. Por esta razón, la Cámara le había concedido cuatro meses fuera

\footnotetext{
${ }^{41}$ AGI, Guadalajara, 553, f. 274.

AGI, Guadalajara, 553, f. 274.

AGI, Guadalajara, 552, f. 146.

4 AGI, Guadalajara, 552, f. 139.

45 AGI, Guadalajara, 553, f. 292.
} 
de Madrid y sitios reales para recobrar su salud. No obstante, según consulta de la Cámara, de marzo de 1803, dicho personaje continuó prorrogando su salida bajo el mismo pretexto, «de forma que va a ser año y medio que se le nombró y no hay el menor indicio de que se disponga a emprender el viaje para pasar a su iglesia, hallándose en esta corte» ${ }^{46}$. Por lo tanto, ese mismo año, se decidió revocar su nombramiento.

Por último, está el caso de Mariano José de Cabo Franco, presbítero del arzobispado de México, residente en la corte en el momento de ser nombrado racionero, en 1805. Este personaje, para justificar su renuncia, decidió levantar un informe con cinco testigos argumentando lo dañino que el clima neoleonés podía ser para su salud. Antonio Agustín de Mayorga, por ejemplo, señaló «que habiendo estado y permanecido en Monterrey experimentó que su temperamento es muy malo y enfermo a causa de ser extremo caliente y húmedo, sus aires impuros, que reinan constantemente fiebres y tercianas que por lo regular declinan en pútridas» ${ }^{47}$, razón por la cual, el mencionado Cabo Franco no podría permanecer en aquella ciudad. Por su parte, Pedro de Nava, teniente general de los reales ejércitos, argumentó en su favor:

... no tengo reparo en exponer que la ciudad de Monterrey, capital del Nuevo Reino de León, donde se halla la catedral, no se considera por saludable a causa de ser su temperamento muy ardiente en verano por el reflejo del sol de una montaña que tiene vecina, lo que obligó a uno de sus primeros obispos a edificar casa en una altura inmediata a la ciudad para liberarse en parte de los excesivos calores. Como los indios bárbaros de aquellas fronteras han solido hacer hasta allí sus incursiones, se necesita varias veces para ir con seguridad llevar escolta de tropa para liberarse de caer en sus manos, lo que experimenté y vi cuando pasé reconociendo el estado militar de aquella provincia que con las demás internas estaba bajo de mi mando ${ }^{48}$.

Según se aprecia, las raciones fueron las prebendas menos deseadas de la catedral de Monterrey. Lo más usual fue rechazarlas argumentando alguna enfermedad, lo cual permitía hacerlo sin perder la posibilidad de ser considerado para otras prebendas. No obstante, esto no quiere decir que todos los prebendados mintieran; tiendo a pensar por ejemplo, que el bachiller Juan Nepomuceno Serralde, presentado en 1799, cura de los valles de Sabinas en la diócesis del Nuevo Reino de León, no mentía cuando pidió su renuncia argumentando que «de día en día va a más el quebranto de mi salud y con particularidad la falta de vista que me impide hasta de rezar el oficio divino» ${ }^{49}$. A pesar de ello, lo más común fue rechazar las raciones porque sus emolumentos

\footnotetext{
46 AGI, Guadalajara, 553, f. 294.

47 AGI, Guadalajara, 553, f. 318.

48 AGI, Guadalajara, 553, f. 318.

49 AGI, Guadalajara, 553, f. 262.
}

Hispania, 2020, vol. LXXX, n. ${ }^{\circ} 265$, mayo-agosto, págs. 467-496, ISSN: 0018-2141, e-ISSN: 1988-8368 https://doi.org/10.3989/hispania.2020.013 
no justificaban el viaje y la estancia en Monterrey. Lo anterior es muy evidente pues quienes las renunciaron generalmente residían en obispados alejados de la sede neolonesa y poseían rentas mejores.

Lo anterior nos lleva a preguntarnos por el perfil de quienes sí acudieron a servir sus beneficios. De quienes ocuparon las primeras raciones creadas hemos hablado antes, se trató del bachiller Miguel Sánchez Navarro, entonces cura de Monclova, en la provincia de Coahuila; del doctor Andrés Ymar, europeo; y del bachiller Francisco López, cura del presidio de Mazatlán, en el obispado de Sonora. En 1799 se presentó a tres nuevos racioneros: el licenciado Joseph Manuel Tamayo y Mastranzo, capellán de la Real Audiencia de Guadalajara; el doctor Francisco de Avellafuerte, cura, vicario y juez eclesiástico de Irapuato, en el obispado de Michoacán ${ }^{50}$; y el bachiller Domingo de Ugarte y Burgoa, «rector del colegio seminario conciliar de esa diócesis [Nuevo Reino de León] y examinador sinodal de ella $\rangle^{51}$. Finalmente, entre 1802 y 1805 ingresaron cinco nuevos racioneros. Estos fueron, el bachiller Pedro del Hombre, clérigo domiciliario del obispado de Durango donde era cura, vicario y juez eclesiástico del partido de Mezquital ${ }^{52}$; el bachiller Alejandro Vicente de la Garza, comisario del Santo Oficio y cura, vicario y juez eclesiástico de la villa de San Juan Bautista Cadereyta, en el obispado neolonés ${ }^{53}$; Antonio Martín Fajardo, teniente de cura de la villa de Hincha, en la diócesis de Santo Domingo ${ }^{54}$; Juan Francisco Arce y Rosales, cura del obispado de Durango; y el bachiller Mariano Joseph Monzón. Este último personaje había servido como maestro de ceremonias y capellán de coro de la catedral de Monterrey desde que se constituyó el cabildo. Asimismo, fue promotor fiscal de la diócesis. Entre sus méritos estaba, además, ser «descendiente de los primeros pobladores, pacificadores y conquistadores de aquellas provincias que han defendido las fronteras de la costa en las continuas incursiones de los indios bárbaros $)^{55}$. Cuando se le otorgó su ración se dijo, además, que esto se hacía «en atención también a que las prebendas de la catedral de Monterrey, por la cortedad de sus rentas, no acomodan a otros sujetos de fuera del obispado, de lo que ha resultado haberlas renunciado». Lo anterior permite observar que la mayoría de las raciones de Linares fueron cubiertas por clérigos que ya residían en el mismo obispado. Resalta, también, como se puede ver en el cuadro 4, que la mayoría de quienes aceptaron las raciones poseían solo el grado de bachilleres. Fue muy difícil que

\footnotetext{
50 AGI, Guadalajara, 553, f. 79.

51 AGI, Guadalajara, 553, f. 83.

${ }_{52}$ AGI, Guadalajara, 552, f. 149.

53 AGI, Guadalajara, 553, f. 91.

${ }_{54}$ AGI, Guadalajara, 552, f. 154.

55 AGI, Guadalajara, 552, f. 156.
}

Hispania, 2020, vol. LXXX, n. ${ }^{\circ}$ 265, mayo-agosto, págs. 467-496, ISSN: 0018-2141, e-ISSN: 1988-8368 https://doi.org/10.3989/hispania.2020.013 
alguien con grados universitarios mayores aceptara una ración en aquel cabildo fronterizo.

CUAdro 4. Racioneros del cabildo eclesiástico entre 1790-1808

\begin{tabular}{|c|c|c|c|}
\hline Nombre & $\begin{array}{c}\text { Año de } \\
\text { presentación }\end{array}$ & Origen & Grado \\
\hline Joseph Miguel Sánchez Navarro & 1790 & $\mathrm{~A}$ & Bachiller \\
\hline Antonio Andrés Ymar y Altolaguirre & 1792 & $\mathrm{E}$ & Doctor \\
\hline Joseph Francisco López Portillo & 1795 & $\mathrm{~A}$ & Bachiller \\
\hline Francisco de Avellafuerte & 1799 & $?$ & Doctor \\
\hline Domingo de Ugarte y Burgoa & 1799 & $\mathrm{E}$ & Bachiller \\
\hline Joseph Manuel Tamayo & 1799 & $\mathrm{~A}$ & Bachiller \\
\hline Pedro del Hombre & 1802 & $\mathrm{E}$ & Bachiller \\
\hline Alejandro Vicente de la Garza & 1803 & $\mathrm{~A}$ & Bachiller \\
\hline Mariano Joseph Monzón & 1805 & $\mathrm{~A}$ & Bachiller \\
\hline Juan Francisco Arce y Rosales & 1805 & $\mathrm{~A}$ & Bachiller \\
\hline
\end{tabular}

Fuente: elaboración propia a partir de AGI, Guadalajara, 552 y AGI, Guadalajara, 553.

\section{DIEZMOS Y PREBENDAS}

Si bien el cabildo de Monterrey inició sus funciones con seis miembros en 1791, al finalizar el siglo el cabildo estaba conformado por 17 prebendados. Sin embargo, los miembros del cabildo no vieron con buenos ojos la decisión de la Corona de aumentar el número de sillas en el coro en 1797. Las reacciones tomadas por el cuerpo capitular nos abren una ventana a otro aspecto importante de la historia de la diócesis: la de los diezmos.

Cuando el cabildo supo de la determinación del rey de aumentar el número de prebendas en Linares, empezó gestiones a través de su procurador en la corte, don Gregorio Riestra, para tratar de suspender su aplicación. En consulta de la Cámara de Indias de septiembre de 1800 se leyó la solicitud de dicho apoderado. En ella se hacía recuento de cómo el rey había autorizado, por consulta del Consejo de Indias de 11 de septiembre de 1797:

... el aumento de prebendas de aquella iglesia de lo que ha resultado la indotación de sus dignidades y canonjías y que no concurran opositores a las vacantes de 
oficio como ha sucedido con la magistral, siendo también un motivo poderoso para que o la iglesia quede sin ministros o no concurran los beneméritos ${ }^{56}$.

Lo anterior lo había expuesto el cabildo luego de que en 1802 se pusieran edictos convocatorios para las canonjías de oficio lectoral y magistral de reciente creación, a las cuales no se habían presentado concursantes ${ }^{57}$. Dicha convocatoria hubo que repetirla en 1803, logrando la ocupación de dichas prebendas hasta 1805. Como hemos expuesto arriba, la razón primordial de este rechazó radicó en que dichas prebendas estaban reservadas, en las diversas catedrales, para personajes con importantes carreras universitarias, no obstante, quienes cumplían con dicho requisito difícilmente querían concursar por las canonjías de Linares. El cabildo insistía en que, al crear las nuevas piezas capitulares, las rentas de éstas se habían disminuido, generando que pocos clérigos quisieran ocuparlas. A pesar de ello, en febrero de 1801 la Cámara había determinado:

En consecuencia de la anterior resolución por la que se remitió a su informe la instancia precedente del deán y cabildo de la iglesia catedral del Nuevo Reino de León, dice este tribunal que en vista de ella y de lo expuesto por el fiscal en su respuesta que original acompaña reconociendo por una parte que las razones representadas por el cabildo sin la menor comprobación no son bastantes para suspender lo resuelto por V.M. a consulta de 11 de septiembre de 1797 hecha con presencia de un expediente debidamente instruido en el superior gobierno de México, y por la otra que la renuncia de un racionero electo y falta de opositores a la magistral pudo haber provenido de otras causas ${ }^{58}$.

Con esta observación, el rey decidió ratificar la creación de las nuevas prebendas. A partir de ese momento el cabildo estaría constituido ya no por seis prebendados, como había iniciado, sino por 17: cinco dignidades, cuatro canónigos de oficios, dos de gracia y seis racioneros. Todo indica que la determinación real se apoyó en el aumento de los diezmos ocurrida entre 1797-1800. En 1790 se recaudaban 80.691 pesos, de los cuales, una vez restados los gastos de recaudación, quedaba para la catedral y sus ministros la suma líquida de 60.917 pesos. Para 1800 el monto líquido para repartir era ya de 101.979 pesos $^{59}$. Suma que no era despreciable, aunque estaba lejos de lo recaudado por una catedral como la

${ }^{56}$ AGI, Guadalajara, 552, f. 128.

57 El 31 de agosto de 1802 se comisionó a los prebendados Feliu (deán), Canalizo (arcediano) y Zárate (doctoral) para que lanzaran la convocatoria del concurso a las canonjías penitenciaria, magistral y lectoral. La primera vacante por muerte del licenciado don José Antonio de la Peña y las otras dos de nueva creación, AHAM, Acuerdos de cabildo, libro 2, sesión de 31/08/1802, fs. 40-40v.

58 AGI, Guadalajara, 552, f. 130-131.

59 AGN, Indiferente Virreinal, caja 5485, expediente 006. 
metropolitana de México que, entre 1785-1789, obtuvo como monto líquido repartible la cantidad de 419.530 pesos anuales. Esta cantidad aumentó entre 1806-1810, periodo en el cual la contaduría repartió 510.082 pesos anuales ${ }^{60}$.

Gráfica 1. Diezmos del obispado de Monterrey, 1790-1800

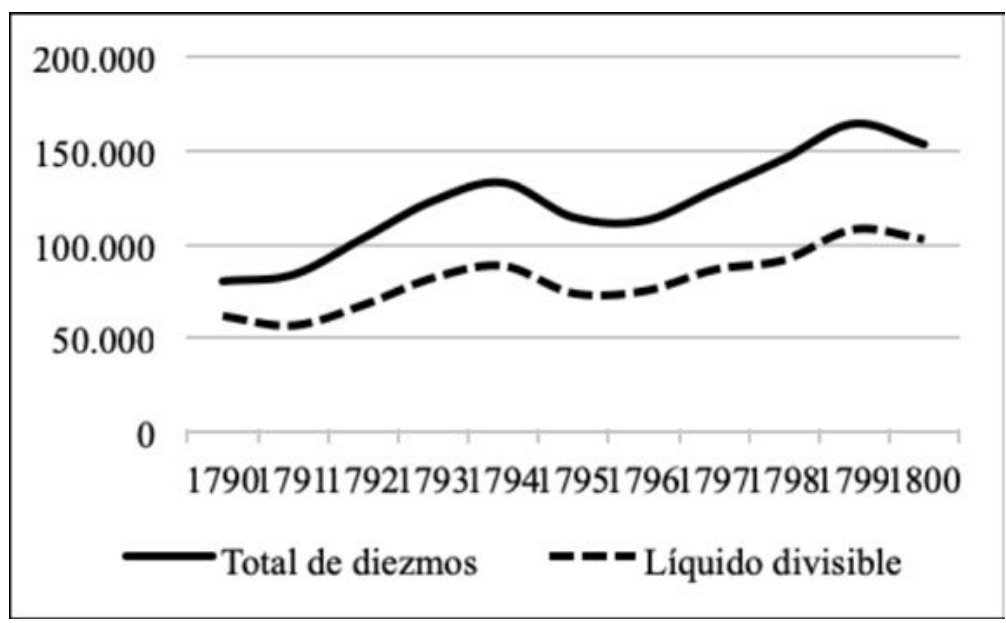

Fuente: elaboración propia a partir de AGN, Indiferente Virreinal, caja 5485, expediente 006.

Por su parte, el repartimiento en la catedral michoacana fue de 360.628 pesos en 1799. Para 1807, la catedral de Monterrey seguía recaudando poco menos de 150 mil pesos. Como puede apreciarse, dicha catedral estaba lejos de ser la más pobre del virreinato. De acuerdo con Víctor Hugo Medina, el total recaudado por la catedral de Yucatán en 1795 fue de apenas 25.472 pesos, cantidad irrisoria que dejaba al obispo una cuarta episcopal de apenas 6.198 pesos, mientras que la cuarta del prelado de Linares fue de 28.087 pesos en 1799. A pesar de lo anterior, según hemos apuntado, varios clérigos prefirieron desistir en espera de mejores nombramientos. Visto esto, es evidente que las renuncias se llevaban a cabo no por un mero desinterés económico, sino por la condición de frontera de aquella catedral y el poco prestigio que representaba ocupar sus prebendas. Ir a Monterrey implicaba, además, alejarse de las redes políticas del centro del virreinato que podían garantizar futuros ascensos en las catedrales más importantes. Debido a esto, la Corona optó por nombrar en estas prebendas a clérigos americanos que tuvieran experiencia en los territorios septentrionales. Lo anterior contrastó con la disposición emitida por el rey en 1771 para

\footnotetext{
${ }^{60}$ ORTEGA GONZÁLEZ, 2010: 77.
} 
reducir a un tercio la presencia de criollos en los cabildos eclesiásticos ${ }^{61}$. Esto llevó a constituir un cabildo con mayoría americana.

Cuadro 5. Miembros del cabildo eclesiástico de Monterrey, 1807

\begin{tabular}{|c|c|c|c|}
\hline Nombre & Prebenda & Grado & Origen \\
\hline Andrés Feliu & Deán & Doctor & E \\
\hline Antonio Ramón Canalizo & Arcediano & Doctor & A \\
\hline Andrés de Ymar y Altolaguirre & Chantre & Doctor & E \\
\hline Francisco López Portillo & Maestrescuela & Bachiller & A \\
\hline Joseph María Gómez de Castro & Tesorero & Bachiller & A \\
\hline Miguel Ignacio de Zárate & Doctoral & Doctor & A \\
\hline Domingo de Ugarte & Penitenciario & Doctor & E \\
\hline José Bernardino Cantú & Magistral & Doctor & A \\
\hline Juan José de la Garza & Lectoral & Licenciado & A \\
\hline Juan Isidro Campos & Canónigo & Sin información & E \\
\hline Joseph Vivero & Canónigo & Licenciado & A \\
\hline Domingo de Ugarte y Burgoa & Racionero & Bachiller & E \\
\hline Joseph Manuel Tamayo & Racionero & Bachiller & A \\
\hline Pedro del Hombre & Racionero & Bachiller & E \\
\hline Alejandro Vicente de la Garza & Racionero & Bachiller & A \\
\hline Mariano Joseph Monzón & Racionero & Bachiller & A \\
\hline Juan Francisco Arce y Rosales & Racionero & Bachiller & A \\
\hline
\end{tabular}

Fuente: elaboración propia a partir de AGI, Guadalajara, 552; AGI, Guadalajara, 553 y AHAM, Acuerdos de cabildo.

En este sentido, las prebendas de la catedral de Monterrey sí se convirtieron en las preseas del clero local y regional. Pensemos por ejemplo en las rentas de los curas del obispado. Entre 1792 y 1794 la red parroquial del obispado del Nuevo Reino de León estaba compuesta por parroquias que, en su mayoría, poseían rentas anuales de menos de mil pesos. De 32 parroquias enumeradas en un listado elaborado sobre el pago del subsidio eclesiástico, encontramos que 11 curatos obtenían

${ }^{61}$ GONZÁLEZ ARIAS, 2016: 277.

Hispania, 2020, vol. LXXX, n. ${ }^{\circ}$ 265, mayo-agosto, págs. 467-496, ISSN: 0018-2141, e-ISSN: 1988-8368 https://doi.org/10.3989/hispania.2020.013 
menos de 500 pesos en rentas; 16 generaban más de 500 pero menos de mil; tres generaba entre 1.000 y 1.500 pesos; una entre 1.500 y 2.000 ; y una más generaba más de dos mil pesos ${ }^{62}$. En dicho listado no aparecen todas las parroquias del obispado (para 1795 la red parroquial se componía de 46 curatos), por ejemplo, no se enlista la de Saltillo que era la más rica, con rentas que seguramente superaban los dos mil pesos. Tampoco aparecen las parroquias de Pilón, Labradores y Laredo. No obstante, este listado nos da una idea de las condiciones económicas de los curatos. Como se aprecia en el cuadro seis, 27 parroquias de una lista de 32 poseían rentas de menos de mil pesos. Para estos curas una prebenda catedralicia bien podía ser una recompensa a su carrera eclesiástica, no sólo por el salario sino por el prestigio social que esto brindaba a nivel regional.

CUAdro 6. Parroquias y sus rentas anuales en el obispado de Monterrey, 1792-1794

\begin{tabular}{|c|c|c|c|c|c|}
\hline Parroquia & Renta & Parroquia & Renta & Parroquia & Renta \\
\hline Tlaxcala del Saltillo & 881 & Salinas & 1.151 & Santander & 304 \\
\hline Cerralvo & 452 & Hoyos & 1.420 & Aguayo & 432 \\
\hline Boca de Leones & 2.461 & Santa Rosa & 515 & Santa Bárbara & 643 \\
\hline Linares & 983 & San Nicolás de Croix & 592 & Güemes & 350 \\
\hline Sagrario de Monterrey & 1.807 & Cruillas & 528 & Taumabe & 700 \\
\hline Monclova & 550 & $\begin{array}{l}\text { San Carlos de } \\
\text { Tamaulipas }\end{array}$ & 622 & Tula & 1.241 \\
\hline Camargo & 900 & Padilla & 388 & Palmillas & 600 \\
\hline Mier & 560 & Santillana & 287 & Llera & 370 \\
\hline Reynosa & 911 & Soto la Marina & 600 & $\begin{array}{l}\text { Real de los } \\
\text { Infantes }\end{array}$ & 200 \\
\hline Punta de Lampazos & 797 & $\begin{array}{c}\text { San Fernando de las } \\
\text { Presas }\end{array}$ & 244 & Escandón & 400 \\
\hline Río Blanco & 600 & Burgos & 254 & & \\
\hline
\end{tabular}

Fuente: elaboración propia a partir de AGN, Indiferente Virreinal, caja 5085, expediente 002.

Por otro lado, las ya de por sí bajas rentas de los prebendados se vieron afectadas por diversas medidas tomadas por la Corona a finales del siglo XVIII. Desde el siglo XVII se habían impuesto a los prebendados de las catedrales

${ }^{62}$ AGN, Indiferente Virreinal, caja 5085, expediente 002. 
novohispanas el pago de la «media annata» y la «mesada», correspondientes a medio año y a un mes de salario, respectivamente ${ }^{63}$. A inicios del siglo XVIII se sumó el cobro del subsidio eclesiástico, concedido al rey por el papa (3 entre 1693-1740). Además, poco antes de la concesión del tercer subsidio, la Corona se adjudicó todas las rentas de las vacantes de dignidades, canonjías, raciones y medias raciones ${ }^{64}$. En 1800 se implementó un nuevo subsidio y en 1802 la exacción de una «anualidad» (un año de salario) de todos los beneficios de las iglesias de España e Indias, cuyo objetivo era la extinción de los vales reales.

En el obispado del Nuevo Reino de León sabemos que desde el establecimiento del cabildo eclesiástico, en 1791, se exigía el pago de la media annata. Lo común era que todo prebendado, al recibir su nombramiento, presentara fianzas ante el tesorero de las cajas reales del Saltillo, comprometiéndose al pago de las cantidades correspondientes. Dicha obligación era tan importante que, sin ella, el cabildo no podía dar posesión de ninguna prebenda. Ante la merma que esto representaba a las cortas rentas de la catedral, el cabildo presentó solicitudes en 1792 y 1794 a la Corona para que se anulara dicho cobro, no obstante, nunca ocurrió ${ }^{65}$. A ello colaboró, por un lado, la urgencia de la Corona en tiempos de guerra, y por el otro, el aumento de diezmos a fines de siglo, que permitió sortear mejor semejante impuesto. Lo que sí ocurrió en algún momento fue la suspensión del pago de mesada, pues en la presentación de prebendados de 1792 ya se menciona que se excluye dicha carga ${ }^{66}$.

En cuanto al subsidio se refiere, su pago parece haberse iniciado de forma constante hasta inicios del siglo XIX, aunque su pago se había ordenado desde 1790. En 1793, el obispo Ambrosio de Llanos y Valdés nombró como su apoderado para tomar posesión del obispado, y como gobernador del mismo, al entonces deán don Andrés Feliu, a quien comisionó, además, para el cobro del «real subsidio». Sin embargo, en 1794 el cabildo y el obispo seguían sin pagarlo, según se dijo, «porque no se les ha regulado lo que les toca por no haberse hecho repartimientos» ${ }^{67}$. Si bien el cabildo aún no pagaba el subsidio, a los curas párrocos del obispado se les había empezado a cobrar desde 1791. Respecto a las vacantes, la Corona se adjudicó las de Linares desde diciembre de $1797^{68}$. No es extraño, pues, que lo haya hecho justo el mismo año en que creó 11 nuevas prebendas para aquella catedral. En el caso de otras catedrales, como la de México, la Corona realizó una cantidad inusualmente alta de nombramientos; si recordamos que por cada nombramiento había que pagar mesada,

\footnotetext{
${ }^{63}$ GONZÁLEZ ARIAS, 2010: 101.

${ }^{64}$ AGUIRRE SALVADOR, 2012: 292, 297 y 318.

${ }^{65}$ AGI, Guadalajara, 552.

${ }^{66}$ AGI, Guadalajara, 553, f. 16.

${ }^{67}$ AGI, Guadalajara, 553, f. 16.

68 AGI, Indiferente Virreinal, caja 5485, expediente 006.
} 
media annata y anualidad, cabe preguntarse si aquellos reacomodos no servían como un medio para percibir recursos ${ }^{69}$.

En 1801 llegaron a Monterrey las noticias del nuevo subsidio, en esa ocasión, según se dijo, teniendo en cuenta «las necesidades del Estado», se acordó adelantar los «siete mil ochocientos sesenta y seis pesos asignados a este obispado del depósito de novenos beneficiales con la calidad de reemplazarlos luego»». Con esta medida el cabildo buscó paliar en cierta forma la fiscalización que de las rentas catedralicias había empezado la Corona desde finales del siglo XVIII, es decir, se utilizaban los propios novenos del rey y los cuatro novenos para el pago de dicho subsidio, sin tocar la cuarta episcopal ni la mesa capitu$\operatorname{lar}^{70}$. La ventaja que tuvo el cabildo de Linares para hacerlo así, fue que apenas se encontraba construyendo un aparato de recaudación con todos los riesgos que ello conllevaba en un territorio aun poco pacificado, advirtiéndole al «excelentísimo señor virrey [...] la imposibilidad que tiene este cabildo de graduar la exacción sobre sus rentas por no haberse hecho hasta la presente, repartimientos $\rangle^{71}$. Al año siguiente, una medida similar se tomó tras la solicitud de pago de un segundo subsidio. Esto permitió al cabildo negociar con la Corona el que el sobrante de los cuatro novenos, luego de pagados los sínodos de algunos curas, se sumara a la mesa capitular, lo cual parece que se consiguió en $1802^{72}$.

Las dificultades en el cobro de los diezmos permitieron al cabildo también negociar otras prerrogativas, además de los novenos beneficiales. Otra de ellas fue el pago de diezmos por parte de presidios y misiones. El 5 de mayo de 1801, por ejemplo, se comentó en sesión capitular que los administradores de Texas y del presidio de Río Grande les avisaban, con fecha de 16 y 22 del pasado, haberles prevenido el gobernador que cesasen en la recaudación y cobro del diezmo, dando a entender que los «vecinos de aquel lugar se creían exceptuados de pagarlos $\rangle^{73}$. Todo indica que una Real Cédula de octubre de 1800 había exceptuado del pago de diezmos a algunas misiones y presidios. No obstante, el cabildo, por medio del canónigo doctoral, envió una representación al comandante general de Provincias Internas «sobre paga de diezmos de los presidios de Coahuila y Texas» ${ }^{74}$. Sin embargo, a pesar de la representación del cabildo,

${ }^{69}$ CASTILlO FLORES, 2018a.

${ }^{70}$ El reparto de los diezmos se llevaba a cabo de la siguiente manera: el total de lo recaudado se dividía en cuatro partes. Una de ellas era la cuarta episcopal y otra era la mesa capitular. Las dos cuartas restantes se dividían en nueve partes iguales, de las cuales dos eran para el rey (novenos reales), una y media para el hospital de la diócesis y otro tanto similar para la fábrica de la catedral. Los cuatro novenos restantes (novenos beneficiales) se ocupaban en algunas catedrales para el pago de los curas y el sobrante se sumaba a la mesa capitular.

71 AHAM, Acuerdos de cabildo, libro 2, sesión de 06/06/1801, fs. 18v-19.

72 AHAM, Acuerdos de cabildo, libro 2, sesión de 23/07/1802, fs. 37-38.

73 AHAM, Acuerdos de cabildo, libro 2, sesión de 05/10/1801, fs. 24v-25v.

${ }^{74}$ AHAM, Acuerdos de cabildo, libro 2, sesión de 10/10/1801, fs. 26-26v. 
a fines de año se leyó en sesión capitular un escrito por el cual dicho comandante se negaba «a la suspensión de la Real Cédula de 17 de octubre de 1800 que liberta a los presidios y compañías volantes de las mismas, la satisfacción de diezmos y primicias, y también a los vecinos de sus poblaciones, haciendas y estancias ${ }^{75}$. La orden continuó vigente hasta que, en 1804, se consiguió la publicación de una «orden del señor comandante general de Provincias Internas para que paguen diezmos los vecinos de todos aquellos presidios según y cómo dio la providencia la Junta Superior de Real Hacienda a solicitud de este cabildo» ${ }^{76}$.

Lo anterior ocasionó varios problemas al cabildo que, todavía en 1802, seguía poniendo en orden los diezmos de la década pasada. Estas circunstancias fueron, entre otras ya mencionadas, las responsables de que pocos prebendados quisieran ir a Monterrey a servir las prebendas catedralicias. No obstante, según hemos visto, también el cabildo supo aprovechar estas debilidades para negociar con la Corona y para, como lo hicieron otros cabildos ${ }^{77}$, retrasar la aplicación de algunas de sus medidas fiscalizadoras. Otra de ellas, por ejemplo, fue el intento realizado en 1802 de que los diezmos recabados se pusieran bajo control de las Reales Cajas de San Luis Potosí, capital de la intendencia del mismo nombre, creada en 1786, y que abarcaba el territorio del obispado de Linares. De acuerdo con un oficio del virrey, de 21 de diciembre de 1801, el contador real de diezmos de la catedral de Monterrey, le había informado que ante la inseguridad de los montos recabados, sugería para «precaver el más leve recelo [...] mandarlos en depósito en las Reales Cajas de San Luis Potosí, quedando a este cabildo la facultad de librar lo que necesitase, enterando lo pertinente a reales novenos y vacantes $\rangle^{78}$. En aquella ocasión se insistió en que el cabildo debía informar los montos totales de los cuadrantes de los diezmos. En respuesta de agosto de 1802, el cabildo informó al virrey «la seguridad con que en el día se hallaban los caudales certificándolo con lo que expusiesen el señor gobernador de la provincia y el mismo contador en virtud de oficios». La intención fue subrayar que no era necesario trasladar los montos a ninguna otra parte, sino que éstos debían resguardarse en la propia clavería de la catedral. Asimismo, avisó de que se estaban sacando los cuadrantes y se avisaría en su momento de los montos existentes que pertenecían al rey ${ }^{79}$.

El cabildo, sin embargo, continuó retrasando la entrega de cuadrantes. En 1804 un nuevo oficio del virrey fue leído en sesión capitular, dicho oficio se

\footnotetext{
75 AHAM, Acuerdos de cabildo, libro 2, sesión de 22/12/1801, fs. 27v-28v.

76 AHAM, Acuerdos de cabildo, libro 2, sesión de 5/10/1804, fs. 77-78v.

77 Véase las medidas implementadas por el cabildo poblano en CERVANTES BELLO, 2008: 279-306.

78 AHAM, Acuerdos de cabildo, libro 2, sesión de 06/08/1802, fs. 38-39v.

79 AHAM, Acuerdos de cabildo, libro 2, sesión de 06/08/1802, fs. 38-39v.
} 
acompañaba de una Real Orden de 30 de noviembre de 1804, y de un oficio del gobernador de La Habana de 19 de febrero del mismo año «en que pinta las necesidades del Estado, pidiendo se franquee por este cabildo lo que permitan sus proporciones para remedio de las graves congojas de la metrópoli y posesiones de América». El oficio hacía referencia al estado de guerra que, desde finales del siglo XVIII, había mantenido la Corona, particularmente con Inglaterra. Para subsanar estas circunstancias, el rey había recurrido a préstamos forzosos y graciosos con miras a subsanar al Real Erario. La catedral de Monterrey no quedó al margen. Sin embargo, nuevamente el cabildo decidió optar por la medida recurrente, adelantar las cantidades existentes en el arca común de vacantes y reales novenos, con la promesa de reponerlo después. Esto, se volvió a insistir,

... en atención a que por los malos años, por el poco valor de los frutos de diezmos, que ha sido preciso fiarlos por más de un año, se han demorado y demorarán los cuadrantes de diezmos, a más de los pagos que anualmente se están verificando para la satisfacción de los donativos y suplementos de subsidio concedido al rey ${ }^{80}$.

Esta respuesta deja ver la estrategia del cabildo para evitar que se tocaran las cuartas capitular y episcopal, además, se hace notar que desde la década anterior el rey había pedido algunos donativos a aquella corporación. Las solicitudes de préstamos no cesaron con el nuevo siglo, antes bien se acrecentaron a partir de 1808, luego de las abdicaciones de Bayona. Ese año se leyó una nueva carta del virrey en la cual pedía un «donativo gracioso para socorrer las actuales urgencias de la monarquía ${ }^{81}$. En aquella ocasión y ante circunstancias tan apremiantes, el cabildo, previa consulta con el prelado que se encontraba en Saltillo, decidió donar 10 mil pesos «del ramo de fábrica». Hay que notar que dicha cantidad salió nuevamente de un ramo ajeno a los dineros de los prebendados y del obispo. Además de ello, dicho cabildo en carta al virrey le señaló:

... que desde el establecimiento de este cabildo se ha ido acopiando lo que produce el noveno y medio de fábrica y casa escusada para cuando hubiese efectos y demás necesario para paramentos, vasos sagrados y demás alhajas necesarias para el culto divino, por carecer de todo esta santa iglesia, con motivo de la suma carestía en que se ven todas las cosas a causa de la guerra con varias naciones por espacio de quince años ${ }^{82}$.

Como es sabido, las complicaciones apenas comenzaban tanto para la península como para la Nueva España. Un año después la Junta Suprema

\footnotetext{
${ }^{80}$ AHAM, Acuerdos de cabildo, libro 2, sesión de 4/05/1804, fs. 88v-89v.

81 AHAM, Acuerdos de cabildo, libro 2, sesión de 24/10/1808, fs. 102v-103.

82 AHAM, Acuerdos de cabildo, libro 2, sesión de 24/10/1808, fs. 102v-103.
} 
Gubernativa de España e Indias, en representación del rey, estaba tratando de mantener a flote las arcas reales. En septiembre de 1809, envió cartas a Nueva España solicitando la apertura de un empréstito sobre las rentas reales con un interés de cinco por ciento, «para vengar los insultos hechos a nuestra católica religión [y] a nuestro deseado monarca don Fernando $7^{\circ}$ por la nación francesa y lograr de este modo la independencia y constitución española $»^{83}$. Las cosas no podrían ser más apremiantes: se amenazaba ni más ni menos que con la pérdida de la religión y de la Iglesia en manos de los franceses de Bonaparte. Ante estas circunstancias, el cabildo decidió poner a réditos:

... treinta mil pesos del noveno y medio de fábrica, sobre la hipoteca de la renta de Tabaco de esta provincia del Nuevo Reino de León, y sin este gravamen adelantar por vía de préstamo cincuenta mil pesos del arca común por el término de cinco años que finalizarán en todo el de mil ochocientos catorce y se deberán reintegrar parcialmente con el producto de los dos novenos y vacantes de esta santa iglesia en los repartimientos que se formen desde el año de mil ochocientos quince en adelante ${ }^{84}$.

El asunto de la guerra con Francia y el cautiverio de Fernando VII se prolongarían varios años más. Por si fuera poco, en 1810 llegaron noticias del levantamiento de Miguel Hidalgo en el bajío. Como es de imaginarse, un nuevo préstamo fue solicitado a la catedral, esta vez por 100 mil pesos «en calidad de reintegro para la guerra que se hace a los insurgentes del pueblo de Dolores y villa de San Miguel el grande» ${ }^{85}$. Sin afán de alargar el relato de los préstamos, diremos únicamente que en 1820, el cabildo sacaba cuentas aún de los adeudos de la Corona sobre los ramos de fábrica, vacantes y novenos, los cuales alcanzaban la suma de 120.177 pesos $^{86}$. Como se puede apreciar, la fiscalización de las rentas eclesiásticas llevada a cabo por la Corona a finales del siglo XVIII tuvo un fuerte impacto en las rentas del obispado de Linares. Si bien el cabildo procuró amortiguar estas extracciones de capital dirigiéndolas a ramos que no afectaran las cuartas episcopal y capitular, en la práctica dichos préstamos sí impactaron en la conformación del obispado y de la catedral. Las sumas colectadas y prestadas nos hablan no de una catedral pobre, antes bien nos hace reconsiderar el papel de este obispado que había surgido apenas unas décadas atrás y que parecía consolidarse rápidamente en las supuestas tierras pobres y agrestes del septentrión novohispano.

\footnotetext{
83 AHAM, Acuerdos de cabildo, libro 2, sesión de 10/09/1809, fs. 110v-111v.

${ }^{84}$ AHAM, Acuerdos de cabildo, libro 2, sesión de 10/09/1809, fs. 110v-111v.

85 AHAM, Acuerdos de cabildo, libro 2, sesión de 29/10/1810, fs. 126-128.

${ }^{86}$ AGN, Indiferente Virreinal, caja 2905, expediente 032.
} 


\section{Comentarios finales}

El obispado de Linares fue creado por bula papal en 1777 y erigido en 1779 en los territorios de las provincias internas de Oriente. Su fundación, al igual que la del obispado de Sonora, respondió a un intento de la Corona por reforzar su control en el septentrión novohispano aún poco poblado. Era un territorio con fuerte presencia de indios nómadas de guerra cuyas fronteras se mantenían seguras por un corto número de presidios y misiones. Dicho espacio estaba conformado por la Colonia de Nuevo Santander, el Nuevo Reino de León y las provincias de Texas y Coahuila. Las razones principales para crear el obispado fueron, por un lado, la lejanía de estos territorios de sus sedes episcopales de Guadalajara, Michoacán y México; por el otro, incentivar el poblamiento y la cristianización en aquella región de frontera. Si bien para finales del siglo XVIII había ya un importante número de poblaciones en este espacio, su situación era inestable, lo que en ocasiones generaba el abandono de las mismas, dificultando el control del camino hacia la provincia de Texas. El interés de la Corona por este territorio se reforzó a fines del siglo XVIII ante el estado de guerra con potencias como Francia e Inglaterra, que amenazaban las zonas limítrofes del virreinato. La visita de José de Gálvez fue el momento perfecto para echar a andar el proyecto de la creación de los nuevos obispados proyectados para San Luis Potosí, Santander y Sonora. Asimismo, se llegó a pensar en la posibilidad de constituir un nuevo virreinato en el septentrión novohispano. De estos proyectos sólo fueron viables los obispados de Sonora y Santander que, tras diversas disputas por la sede, terminó por instaurarse en la capital del Nuevo Reino de León.

El siguiente paso fue la constitución de un cabildo eclesiástico. Su asentamiento no fue fácil pues muy pocos clérigos con carreras universitarias y con beneficios en diócesis del centro del virreinato quisieron ir a servir una prebenda en Monterrey, ciudad conocida por su clima caluroso y húmedo, además de la presencia de «indios bárbaros» y de escasas rentas. Por tal razón, varios de los presentados a prebendas prefirieron quedarse en sus beneficios antes que trasladarse a una ciudad tan lejana del centro del reino. Lo anterior llevó a que el cabildo terminara por adquirir un rostro local. La mayoría de quienes aceptaron las prebendas neolonesas fueron clérigos que habían servido en parroquias del septentrión. Algunos de ellos, a pesar de ser de origen europeo, llevaban años atendiendo parroquias en Durango o en los recién constituidos obispados de Sonora y Linares. Asimismo, sobresalieron clérigos al servicio de los obispos de dichas diócesis. De manera que, a inicios del siglo XIX, el éxito del obispado se debió a los clérigos locales.

La tarea fue difícil pues, además de las dificultades propias del territorio, el obispado se creó en plena etapa de conflictos bélicos entre las potencias europeas. Dicho estado de guerra ocasionó que la Corona implementara un

Hispania, 2020, vol. LXXX, n. ${ }^{\circ} 265$, mayo-agosto, págs. 467-496, ISSN: 0018-2141, e-ISSN: 1988-8368 https://doi.org/10.3989/hispania.2020.013 
programa de fiscalización sobre la Iglesia de Indias con miras a mantener a flote sus arcas reales. Ello generó que las rentas catedralicias se vieran afectadas y que el asentamiento de la catedral marchara a pasos lentos. La cuestión financiera se recrudeció luego de que Napoleón invadiera España y capturara a Fernando VII en 1808. Por si fuera poco, dos años más tarde, se inició en México la guerra de independencia. Todas estas circunstancias afectaron al recién conformado cabildo eclesiástico. A pesar de ello, es de notable interés el hecho de que las rentas del obispado neoleonés estaban lejos de ser pobres, señal de que hacia 1808-1810 el territorio del noreste estaba consolidándose como un importante territorio político y económico. El cabildo eclesiástico y la catedral de Monterrey fueron, podríamos decir, un acertado proyecto de la Corona a finales del XVIII, proyecto que, por cierto, muy pronto dejó de estar en sus manos.

\section{Bibliografía}

Aguirre Salvador, Rodolfo, Un clero en transición. Población clerical, cambio parroquial y política eclesiástica en el arzobispado de México, 1700-1749, México, UNAM, Instituto de Investigaciones Sobre la Universidad y la Educación/Bonilla Artiaga Editores, 2012.

Castillo Flores, José Gabino, «Francisco Xavier de Lizana y Beaumont: arzobispo de México y virrey de la Nueva España (1802-1811)», en Martha Eugenia García Ugarte (coord.), Ilustración católica, ministerio episcopal y episcopado en México (1758-1829), México, UNAM, Instituto de Investigaciones Sociales, 2018a, tomo I: 200-238.

Castillo Flores, José Gabino, El cabildo eclesiástico de la catedral de México (15301612), Zamora, Michoacan, El Colegio de Michoacán, 2018 b.

Cavazos Garza, Israel, Esbozo histórico del seminario de Monterrey, Monterrey, Universidad de Nuevo León, Centro de Estudios Humanísticos, 1969.

Cervantes Bello, Francisco Javier, «El subsidio y las contribuciones del cabildo eclesiástico de Puebla», en Francisco Xavier Cervantes Bello et al, Poder civil y catolicismo en México, siglos XVI al XIX, Puebla/México, Benemérita Universidad Autónoma de Puebla/Universidad Nacional Autónoma de México, 2008: 279-306.

Enríquez Licón, Dora Elvia, Pocas flores, muchas espinas. Iglesia católica y sociedad en Sonora (1779-1912), México, Pearson/Universidad de Sonora, 2012.

González, José Eleuterio, Apuntes para la historia eclesiástica de las provincias que forman el obispado de Linares, desde su primer origen, hasta que se fijó definitivamente la silla episcopal en Monterrey, Monterrey, Nuevo León, Tip. Relig. de J. Chávez, 1877.

González Arias, Diana, Entre el recelo y la rebeldia: el cabildo eclesiástico de México frente a la fiscalización borbónica, tesis de Licenciatura en Historia, México, UNAM, 2010. 
González Arias, Diana, «Los prebendados del cabildo eclesiástico de México en el cambio de siglo. Provisión de canonjías y dinámicas corporativas, 1789-1808», en Leticia Pérez Puente y Gabino Castillo Flores (coords.), Poder y privilegio: cabildos eclesiásticos en Nueva España, siglos XVI a XIX, México, UNAM, Instituto de Investigaciones sobre la Universidad y la Educación, 2016.

Ibarra González, Ana Carolina, El cabildo catedral de Antequera, Oaxaca y el movimiento insurgente, Zamora, Michoacán, El Colegio de Michoacán, 2000.

Jaramillo Magaña, Juvenal, Una élite eclesiástica en tiempos de crisis. Los capitulares y el cabildo catedral de Valladolid-Morelia (1790-1833), Zamora, Michoacán, El Colegio de Michoacán, Instituto Nacional de Antropología e Historia, 2014.

Martínez, Patricia, El tejido familiar de los Sánchez Navarro, 1805-1840, Saltillo, Ayuntamiento de Saltillo/Archivo Municipal de Saltillo/Archivo para la Memoria de la Universidad Iberoamericana, 2014.

Mazín Gómez, Óscar, El Cabildo catedral de Valladolid de Michoacán, Zamora, Michoacán, El Colegio de Michoacán, 1996.

Ortega González, Carlos Alberto, El ocaso de un impuesto. El diezmo en el arzobispado de México, 1810-1833, tesis de Licenciatura en Historia, México, Instituto de Investigaciones José María Luis Mora, 2010.

Paniagua Pérez, Jesús, «El proyecto fracasado del último obispado del norte de la Nueva España. Hacia la creación de la diócesis de Nuevo México», Anuario de Estudios Americanos, 70/1 (Sevilla, 2013): 99-127.

Pérez Puente, Leticia, «El cabildo y la universidad. Las primeras canonjías de oficio en México (1598-1616)», Histórica, XXXVI/1 (Lima, 2012): 53-96.

Pérez Puente, Leticia y Castillo Flores, Gabino (coords.), Poder y privilegio: cabildos eclesiásticos en Nueva España, siglos XVI a XIX, México, Universidad Nacional Autónoma de México, Instituto de Investigaciones sobre la Universidad y la Educación, 2016.

Sheridan Prieto, Cecilia, «Indios madrineros. Colonizadores tlaxcaltecas en el noreste novohispano», Estudios de Historia Novohispana, 24 (México, 2001): 15-51.

Sheridan Prieto, Cecilia, Fronterización del espacio hacia el norte de la Nueva España, México, CIESAS/Instituto Mora, 2015.

Valdés, Carlos Manuel, Los bárbaros, el rey, la Iglesia. Los nómadas del noreste novohispano frente al Estado español, Saltillo, Coahuila, Universidad Autónoma de Coahuila, 2017.

Recibido: $12 / 02 / 2019$

Aceptado: 30/07/2019

Hispania, 2020, vol. LXXX, n. ${ }^{\circ}$ 265, mayo-agosto, págs. 467-496, ISSN: 0018-2141, e-ISSN: 1988-8368

https://doi.org/10.3989/hispania.2020.013 